First published in Studies in French Cinema 3:2 (2003), 101-109

\title{
The point in time: precise chronology in early Godard
}

'A film is out of date when it doesn't give a true picture of the era it was made in', said Godard in 1960 (Godard 1972: 26), and in 1966: 'All of my films report on the situation of the country, are documents d'actualité ${ }^{1}$ (Godard 1971: 12). My subject here is the actuality of the documents we see and hear in Godard's sixties' films, the truth of the picture given.

Godard has a reputation for having kept pace with his time, a reputation founded in the $1960 \mathrm{~s},{ }^{2}$ when his films held a mirror up to the ephemeral detritus of the real and said it was beautiful. Neon signs, film posters, records on the jukebox, magazine covers...: the film of these passing phenomena celebrates them, and documents them in their place and time. The mirror image implies a certain passivity, and here I wish to illustrate how the reflective function of Godard's films is an active engagement with his time, in fact a critical revision of what it means to be 'of' a time.

Serge Daney comments, somewhere, that Godard was the first to put in a fiction film the newspaper of the day of the shoot (Bergala 1999: 225). Daney may have forgotten the scene in Paris nous appartient (Rivette, 1961), filmed at the beginning of September 1958, where we see the front page of L'Equipe, with the headline announcing Ercole Baldini's victory in cycling's World Road Championship the day before. ${ }^{3}$ Then again, the newspaper is in the hand of Godard himself, cycling fan and extra in Rivette's film, and we can at least say that from the outset he was associated with this cinematic use of found materials. The first shot of $A$ bout de souffle (Godard, 1960), filmed a year later, shows Belmondo reading a current issue of Paris-Flirt (number 137, dated 12 September 1959). From then on, Godard is an artist making art from the quotidian materials around him.

The immediate, contingent quality of these materials is at its highest on the day of the shoot. Each day thereafter the immediacy diminishes, and for the film's first audience - two or three months later, at best - the newspaper of that earlier day is already the past, a vestige of a bygone age. It is all the more so for us, some thirty or forty years later.

To compensate, the object acquires other qualities. Its contingency becomes context, the readable trace of the time from which the film has come to us. Godard's sixties' films are identifiable as sixties' films by - no less than by the date on the credits - an accumulation of chronologically marked ephemera: newspapers, magazines, film posters, advertisements, radio and television broadcasts, pop records... His films, dressed in authentic sixties' costumes, carry forward their own time into our present, offering up the time to us as a matter for contemplation. Thanks to which the past is not dead, nor even past, as Godard (and Faulkner) might say.

This neat scenario is complicated by the chronological specificity of certain of these objects. There is a difference between more general signs of a time - music, art, fashion, literature - and items like newspapers, bearing a specific date that is, 
effectively, their sell-by date. The categorical difference comes in part from this ephemerality, but also from the import of dating itself. Within a film, a date is often a formal feature, establishing a chronology of fictional events within the narrative. A date on a newspaper does this well, but then, almost necessarily, it situates the narrative sometime earlier than the time of filming, and is itself a sign of planning, of artifice. It lacks the immediacy with which Daney credits Godard, the 'actuality' that Godard claims for himself.

At the same time, a newspaper is effective in bringing into play the actuality perhaps of greatest interest to us, now, reading and watching Godard the historian, and that is the set of traces left by political situations and events. It is to these period-bound relics that I shall turn here, more specifically to traces left by reference to the Algerian war.

The first two years of Godard's feature-film making cover the last two of the war, and the war's aftermath features in his work at least as far as Pierrot le fou (1965). His first three films shot in the 1960s all refer in some way to the Algerian war, though one is set in the past, one in the present, and one in the future. Each establishes a peculiar relation to the political through precise use of chronology.

Shot in April and May 1960, Le petit soldat is apparently a record of events two years earlier, the time of the insurrection in Algiers that led, eventually, to De Gaulle's return to power and to the establishment of the Fifth Republic. It is one of very few films by Godard to be formally set in an earlier time; in 1960 he had categorically rejected the idea of making films about the past:

Why not make something current, why do you have to consider present events as something taboo? A film is out of date when it doesn't give a true picture of the era it was made in. (...) I would consider it indecent to make a film today about the resistance. (...) Doing it now is dishonest, impure, and fabricated. (Godard 1972: 26)

The currency of Le petit soldat, its actuality as document, is an issue I shall return to in discussing how it is 'fabricated'.

Une femme est une femme (1961) is one of at least three Godard films of the 1960s set in the future, alongside Alphaville (1965) and Made in USA (1966). Perhaps there are four: Deux ou trois choses que je sais d'elle (1966), that most 'actual' of Godard's pre-'68 films, shows a character listening to radio broadcasts made some time in 1969, and it may be that we are to read this film, like its companion piece Made in USA, as a dialogue between the time of filming, 1966, and the time of the narrative. In this it would also resemble Alphaville and Une femme est une femme, though this 'double-time' structure is a feature of all of Godard's chronology-conscious work, including his most recent feature, Eloge de l'amour (2001), set in 1999 for the first half, then in 1997 for the second.

Une femme est une femme was shot between November 1960 and January 1961 and premiered at Berlin in June 1961; it is set in November 1961. On Friday November $10^{\text {th }}$, to be precise. That date, shown on a calendar consulted by Angela (Anna Karina), is the narrative centre of the film - the next day we see the date has changed to the $11^{\text {th }}-$ but it is thrown off-centre by the accumulated debris of the everyday, 
traces of the time of filming that litter the film, and do not fit the calendar-date. These traces are mostly newspapers with headlines that can be deciphered (L'Equipe, L'Humanité), or magazines with recognisable covers (Marie Claire, Jours de France), but they also include a shot of a television screen showing Agnès Varda's short film Opéra-Mouffe (Varda, 1958), broadcast in November 1960. Of a different order are the cameos by stars of films playing in Paris in November 1960 (Catherine Demongeot from Zazie dans le métro (Malle, 1960) and Marie Dubois from Tirez sur le pianiste (Truffaut, 1960)), but each of these films is also documented as current by more ephemeral period objects. The November issue of Le cinéma chez soi with Catherine Demongeot on the cover is displayed in a bookshop, and the soundtrack EP of Tirez sur le pianiste is displayed in the jukebox that plays Angela's favourite song.

These and similar features conflict with the date on the calendar, but the most striking trace of the non-fit between present and future is the football match that Emile (JeanClaude Brialy) wants to hear on the radio, Barcelona versus Real Madrid. We know straightaway when he comes in and asks if the match is over that there is a problem of chronology, since the calendar says Friday, and a match of this kind would have been played on a Wednesday. However, a little into the scene we hear fragments of radio commentary, and later in the film Emile is reading L'Equipe for Thursday November 24 1960, with the match featured in its headline. Two realities are in conflict, and if the documents of November 1960 win out by sheer force of numbers, there is a hint that the documented reality is also informed by fantasy: the action we hear in the commentary is a goal scored by Del Sol, after a pass from Di Stefano. Real and Barcelona played the two legs of their European Cup quarter final on the $9^{\text {th }}$ and $23^{\text {rd }}$ of November 1960 (2-2 in the first game at Madrid, 2-1 to Barcelona in the second). Accounts of the two games record no goal scored by Del Sol, though we distinctly hear the commentator say 'Goal'. This action, reconstructed for the film, was, I suspect, one of the several perfectly good goals scored by Real Madrid in the away match, disallowed by the thenceforward notorious English referee, Mr Leafe. If so, Godard has allowed to stand, in his sample of commentary, a beautiful goal that could have changed the course of football history. The defeat of Real Madrid ended their run of five successive European cup titles, opening the door for the likes of Benfica, $\mathrm{AC}$ and Inter Milan and Celtic (and also Manchester United).

Though slight, the displacement in time requires explanation. It may just be a matter of opposing the 'vérité' documents of November 1960 and the imaginary narrative of November 1961, making narrative a form of escapism. The film is, for all its narrative whimsy, rich in vérité shots of the Porte Saint-Denis area and its inhabitants. We could call these non-narrative elements a 'chronique', like Jean Rouch's work in Paris that year, with the same cinematographer (Raoul Coutard). But unlike Chronique d'un été (Rouch, 1962), Une femme est une femme appears indifferent to contemporary politics. None of the political events concurrent with the preparation of Une femme est une femme figures in the film: not the trial of Francis Jeanson for running arms for the FLN, nor the 'Manifeste des 121', not even the banning of Godard's Le petit soldat. ${ }^{4}$

As filming began, the trial was in progress of the civilians involved in the uprising in Algiers in January 1960, the 'semaine des barricades'. Earlier that month, De Gaulle had declared that 'Algerian Algeria will have its government', and there were strong fears in Algeria and Paris of renewed terrorism from those supporting an 'Algérie française'. These fears leave their mark on Une femme est une femme: just after 
Angela has said she will sleep with the next man she meets, two policemen arrive to check the apartment, because 'a terrorist has just thrown a bomb on the boulevard'. But Angela doesn't sleep with the policeman, and the political stays out of the unfurling sex-comedy narrative.

The film sets itself in a time that could quite feasibly have been thought to be after the Algerian War: on the basis of De Gaulle's comments an end, for some, seemed in sight. From a historical point of view - by which I mean with the luxury of hindsight - this is ironic, since a year later, in November 1961, Paris was still under the shock of the October $17^{\text {th }}$ massacres, and would see a great deal more street violence, police repression and terrorist bombs before the final peace accords of March 1962.

The future setting of Une femme est une femme is an apolitical gesture, a forgetting of the war, understandable perhaps after the political censorship a month or so earlier of Le petit soldat. But the gesture is not successful: the war remains present as part of a chronology parallel to the narrative. And the effect is not confined to Une femme est une femme. For at least five or six of Godard's sixties films, the home front politics of the Algerian war are part of a parallel chronology inflecting our sense of the fictive events shown. Sometimes more general signs of the time point to that parallel line graffiti in Vivre sa vie and Pierrot le fou, a man carrying a bomb in Bande à part - but the mere mention of a date is in itself a signpost to the parallel chronology of the Algerian war.

Vivre sa vie (1962) appears not to be a film about politics. Passing allusions to the war include the letters GAR scrawled on a wall (the initials of the 'Groupe d'Action et de Résistance', 5 an anti-OAS, anti-terrorist group), but they appear to mean nothing to Nana (Karina). A soldier on leave attracts her attention briefly, but when later in that scene a North African is gunned down by the police, it is 'une histoire politique', we are told, and none of Nana's business.

This political story is chronologically specific, as we know from the period's most explicitly political - and most chronologically explicit - film, Octobre à Paris/October in Paris (1962). (It was directed anonymously by Jacques Panijel, on behalf of the pro-FLN Maurice Audin committee, and banned after its first showing in October 1962.) This film's narrative chronology stretches from October 1961 to February 1962, centring on the brutal repression of pro-FLN demonstrations in each of those months. The internal chronology of Vivre sa vie shadows that of Octobre à Paris, stretching from November 1961 to April 1962. The North African killed by the police in Vivre sa vie is a fugitive from that other chronology, a victim of the repression documented in Octobre à Paris. ${ }^{6}$

The most explicit political allusion in Vivre sa vie is not labelled as such, it is simply a date. The letter Nana is writing after the death of the North African is dated March 30. From this we can reconstruct the internal chronology of the film, but we can also discover a context for reading the allusions made to the real. On March 18 the Evian talks were concluded, and the Algerian war was over. The killing in the café was filmed before this event, ${ }^{7}$ the letter-writing afterwards. As if to mimic the coming of peace, no more political allusions are made in the film from this point on, but the absence of allusion, I would argue, alludes to the fantasy that, from this point on, there will be no more violence, no more repression. March 30 was simply the date of 
the shoot. Nonetheless it carries forward, for the film's audiences later that year, and for us, now, information on how to situate the film in time, and in history.

Le petit soldat is, I have said, set in the past. This setting, like the future date of Une femme est une femme, is a feature of the narrative, delivered by the narrator, voice off: 'Geneva, 13 May 1958'. Against this, the vérité documented in the film is, as in Une femme est une femme, a different time, that of filming, April and May 1960. Datable material proliferates, and all of it relocates the film from May 1958 to April 1960. There is a case to be made for discounting the chronological specificity of the found materials, for not seeking period authenticity in a period film by Godard. He himself, in an interview with L'Express, says that a shot of that magazine's banned issue about 'Hitler: twenty years after' was included because it happened to come out, in Switzerland, at the time of filming: 'It was perfect timing!'. But he adds: 'I imagine the public will see this as a gag, at best; but for me, every detail is always filled with little hidden meanings' (Godard 1972: 27).

Perhaps the deepest repository of hidden meanings in Le petit soldat is that Daneymoment when Bruno Forestier (Michel Subor) buys the paper to read of 'Fresh terrorist attacks in Geneva', with the date at the top of the page, April 7 1960. This looks very much like filming the paper of the day of the shoot, April 7 being a few days into filming. Curious about the detail of the terrorist attacks that trigger the action of the film, I rushed to the archives of La Suisse newspaper to read the story. But the newspaper is a fake: the news in Geneva that day was nothing like so sensational. There were certainly no terrorist bombs being planted in Geneva in early 1960. The page is a montage, serving the narrative's need for terrorist activity of this kind, at this time, in this city. ${ }^{8}$

However, that need alone wouldn't require that we see the date of the newspaper - on the contrary, if the time of the narrative is May 1958, it would be better simply not to include in frame the date at the top of the page. It can only be that we are to read the date, and read something into it. A clue comes five minutes later, when a man on a train is seen reading L'Illustré, the Swiss Paris Match, with the face of General Guisan on the cover. Guisan was the general in charge of the defence of Switzerland during World War Two, a national hero (for the French-speaking Swiss in particular). Guisan died on April 7 1960, the date on the newspaper bought by Bruno. ${ }^{9}$ The opening of the film, then, sets against each other May 131958 and April 7 1960, significant dates for the eminent generals of two nations - De Gaulle and Guisan inviting us to read them against each other. Inevitably, against the great soldier and statesman De Gaulle, Guisan is a 'petit soldat'.

The two times are not resolved: the narrative unfolds as if it began on May 13 1958, but is constantly illustrated with images from April 1960. The reference to 1958 is sustained by sounds, the succession of radio broadcasts that punctuate the film. There are sixteen of them, each time motivated from within the narrative by characters listening to the radio. These broadcasts all refer explicitly to insurrection in Algiers, and through references to specific political figures and events several of the broadcasts can be dated to the week following May 131958.

Several but not all. A number introduce a third time frame, referring not to May ' 58 but to the insurrection in Algiers that occurred almost two years later, in January 
1960: the 'semaine des barricades'. This is, we remember, the action that prompts the trials taking place in Paris in November 1960, during the shooting of Une femme est une femme. The insurrectionists had intended to revive the spirit of May ' 58 , but without this time falling for the lies of De Gaulle and his promise to defend 'L'Algérie française'.

The mixing of reference to the two insurrections is a reading of one against the other, a history lesson in montage, and, paradoxically, a means for making political comment at a precise point in time. Had Le petit soldat been released as planned in Autumn 1960, it would have been playing in Paris as the trial opened, and the press coverage of the trial would have supplied the film's audience with the means necessary to identify exactly the allusions made to the January events. Through the immediacy of the film's political references it would have been read, exactly, as a film of its time. As it is, Le petit soldat was banned for more than two years. On release in January 1963, after more serious insurrections, and after the eventual end of the Algerian war, it had missed its moment, its point in time.

One effect of these missed readings is a recurrent confusion about the nature of the 'anti-terrorist commando' to which Bruno belongs. It is commonly identified with the OAS, the Organisation Armée Secrète, but this is not Pierrot le fou, where the inscription 'OASIS' on the wall of Marianne's apartment invites us to associate the violence represented in that film with the actions of colonel Godard and company. ${ }^{10}$ Le petit soldat was made a year before the creation of the OAS. ${ }^{11}$ The organisation to whch Bruno Forestier belongs in Le petit soldat is, as Noël Simsolo (1970: 102) has pointed out, 'la main rouge' ('the red hand'), the semi-mythical agency created by the French secret services (SDECE) to take the blame for government-sponsored terrorist actions. ${ }^{12}$ The car-bombing of Professor Lachenal in the film is exactly the kind of act for which 'la main rouge' was held responsible, especially after the government's attention turned from the FLN's arms-suppliers to mere apologists and sympathisers. In March 1960, for example, two professors at the University of Liège received 'main rouge' letter-bombs, and one of them, Laperche, was killed. ${ }^{13}$

A clearer indication is found in the name of Forestier's immediate superior in the group, Jacques-Aurélien Mercier. This name is a typically Godardian rebus: 'Jacques' is a trace of the real, taken from the name of the actor, Henri-Jacques Huet (just as Paul Beauvais keeps the name Paul in the film); 'Aurélien' is from Aragon's novel of that name, joining several other references to Aragon in this film (and in almost all Godard's films of the sixties); 'Mercier' points us towards 'la main rouge', whose supposed head of operations was Colonel Marcel-André Mercier, otherwise known as 'le petit Mercier'. Though the Mercier character in the film hasn't the high rank of his namesake, his career is an emblematic résumé of the activities of 'la main rouge'. Like many 'main rouge' agents, he is a veteran of the war in Indo-China: 'We find his trace again in ' 57 in Rotterdam, when the cargo-ship Aramis is blown up, in ' 59 in Frankfurt when Professor Dietrich is assassinated. Now he is in Geneva.' This cv echoes specific action attributed to 'la main rouge', like the sinking in 1958 in Hamburg of the cargo ship Atlas, belonging to the FLN's arms-supplier Peuchart, and the car-bombing in 1959, in Frankfurt, of Peuchart himself. It also evokes the fact that colonel Mercier was based in Switzerland until his expulsion in 1957, as well as the assassination in Geneva of arms dealers in 1958 and 1959. 
The only other detail given in the film that might identify a referent is the mention that the anti-terrorist cell is funded by 'a former Poujadist deputé who had his moment of glory under Vichy'. This is in part a gag, since the funder of the cell is played by the funder of the film, Georges de Beauregard, but there is probably, among the fifty députés elected on Poujade's ticket in 1956, one who had his moment under Vichy, recognisable in the remark. ${ }^{14}$

The publicity accorded the actions of 'la main rouge' would have made the association more obvious in 1960, and the association gives credence still to the actions represented in Le petit soldat, even if in Geneva in 1960 no professors were blown up or radio journalists gunned down.

Le petit soldat is the most complex, chronologically, of the films discussed so far. It appears all the more complex when the chronological specificity of its three narrative times is read against the recurrent memory in the film of earlier times: the 1914-1918 war, the Civil War in Spain and the period 1940-44 in France. These references include the opening (mis)quotation of lines from Aragon's 'Les lilas et les roses', an allusion to Drieu la Rochelle's suicide, and several references to Malraux (a copy of La condition humaine on a bedside table, a still from Espoir on the wall above, etc.).

In the films that come after Le petit soldat, reference to the Algerian war is more straightforward, relatively, because the films are not made to carry the past as an extra burden. By 1965, and Pierrot le fou, the Algerian war is not a parallel chronology, but itself a matter for memory: 'it was like in the Algerian war', says Ferdinand (Belmondo), twice; when he is tortured by the same means used in Le petit soldat, the cinematic intertextuality helps us share this nostalgia; ${ }^{15}$ and the graffiti in Pierrot le fou that should read OAS - Organisation Armée Secrète - has been transformed into OASIS... This derisory escapism effaces the history of only two years before.

Another parallel history takes over, that of the Vietnam war. But in most of Pierrot le fou, and consistently in the films that follow, reference to Vietnam is of a different order: emblematic, iconic, less bound by precise chronology, more 'pop'. An early sequence illustrates the transition. Ferdinand and Marianne (Karina) are in a car listening to the radio, a report of the death of 115 Vietcong. Marianne comments: 'It's terrible how anonymous it is. (...) They say 115 maquisards and it means nothing, but each one is a man, and we know nothing about him (...)' (Godard 1969: 76; my translation). As in Le petit soldat, the radio is the medium, ${ }^{16}$ but here the event mentioned doesn't serve to situate the narrative within a specific historical chronology. Rather, the narrative chronology makes the event emblematic: the scene is supposed to take place on July 14.

The sequence itself is made emblematic by its reworking thirty years later in Histoire(s) du cinéma (Godard, 1998), episode 3A. The shot of Belmondo and the voice of Karina are the ground for a complex montage, pivotal in an argument around resistance and liberation in the period 1940-1945. In Pierrot le fou Marianne comments on a radio broadcast describing the death of 115 Vietcong, effecting a curious shift in terminology: where the newsreader had said 115 men, Marianne speaks of 115 'maquisards', a term that could be used for guerrilla fighters in any context, but which is overwhelmingly associated with the resistance in France between 1940 and 1944. Her choice of the term links the present in Vietnam to 
France's past, a more discrete version of those references in Le petit soldat to Aragon and Hitler connecting events in Algeria with memories of France twenty years before. In 1995, that memory is all that survives. In Histoire( $s)$ du cinéma, the term 'maquisards' is severed from its context. The dead men are no longer Vietcong, they are French resistance fighters, actors in the story of cinema and resistance that Godard is now telling. As a fragment of the past, Pierrot le fou has carried forward not its own time, but the earlier past of which it was already, at the time, the repository. Its own time, in this instance, is not only past, but dead.

I read this as an emblematic warning not to over-invest in the actuality of the documents on display in Godard's sixties films. The constant contemporaneity of these films is only relative. Though we might find, thanks to his mise-en-scène of the period's detritus, that the sixties are not dead, and not even past, the metteur-en-scène himself might not agree. For late Godard, at least, the Godard of Histoire(s) $d u$ cinéma and Eloge de l'amour, the meaningful past is another period entirely, the period of defeat, collaboration, resistance, and holocaust: 1940-1944. 


\section{REFERENCES}

Alleg, H. (1958), La question, Lausanne, La Cité.

Bergala, A. (1999), Nul mieux que Godard, Paris, Cahiers du cinéma.

Braunberger, P. (1987), Cinémémoire, Paris, Editions du Centre Pompidou.

Faligot, R. and P. Krop (1985), La piscine. Les services secrets français 1944-1984, Paris, Seuil.

Godard, J.-L. (1969), 'Pierrot le fou, découpage intégrale'. L'Avant-scène cinéma, 171-172, pp. 72-108.

Godard, J.-L. (1971), Deux ou trois choses que je sais d'elle, Paris, Seuil-Points.

Godard, J.-L. (1972), 'Learning not to be bitter: interview with Jean-Luc Godard on Le petit soldat by Michèle Manceaux' [from L'Express, 16.6.1960], Focus on Godard (ed. R. S. Brown), Englewood Cliffs, NJ, Prentice-Hall, pp.25-27.

Godard, J.-L. (1999), 'Currency of the absolute'. Histoire(s) du cinéma, 3, Munich, ECM, pp. 27-37.

Lack, R.-F. (forthcoming 2003), 'A bout de souffle: the Film of the Book', Literature/Film Quarterly.

Méléro, A. (1997), La main rouge. L’armée secrète de la République, Monaco, Editions du Rocher.

Simsolo, N. (1970), 'Le petit soldat', Image et son 244, pp. 101-106.

${ }^{1}$ The phrase 'documents d'actualité' suggests that Godard's films are documentaries with the immediacy of newsreels ('actualités').

2 'In the 1960s he was the one par excellence who walked at the same hurried pace as his time' (Bergala 1999: 225; my translation).

${ }^{3}$ My thanks to David Forgacs for deciphering this headline for me.

${ }^{4}$ We could imagine Le petit soldat mentioned in a better auto-referential gag than the quip from Alfred (Jean-Paul Belmondo) about not wanting to miss A bout de souffle on television (which had not, as far as I can establish, been broadcast at that point by any station.)

${ }^{5}$ The same graffiti can be seen in a film from the same year as Vivre sa vie, Eric Rohmer's La boulangère de Monceau.

${ }^{6} \mathrm{He}$ is, moreover, played by Laszlo Szabo, the FLN militant in Le petit soldat.

${ }^{7}$ On March 12 (see Braunberger 1987: 176-77).

${ }^{8}$ We should remember that there were also fake newspapers in A bout de souffle, for example: the France Soir with Michel Poiccard's photograph is the newspaper of the day of the shoot with a fake headline and Jean-Paul Belmondo's studio portrait pasted in. For a discussion of similar deceptions in this film, see my article 'A bout de souffle: the Film of the Book' (2003). 
${ }^{9}$ This image of Guisan not only goes against the May 1958 chronology of the narrative, it also twists the April 1960 chronology: Bruno is supposed to have bought a newspaper on April 7; a few hours later he is in the train, where another agent is reading the 'General Guisan' commemorative issue of L'Illustré (which came out on April 21), reading, that is, a magazine mourning the death of the great general some six hours before he actually dies.

${ }^{10}$ I know of no explicit reference in Jean-Luc Godard's work to the coincidence of his name with that of the OAS's head of operations, Colonel Yves Godard.

${ }^{11}$ Though there were secret contacts between the French secret services and OAS representatives in February 1960, the consensus among historians is that the OAS was not active until, at the earliest, late 1960.

${ }^{12}$ For information on 'la main rouge' see Méléro (1997) and Faligot and Krop (1985).

${ }^{13}$ The bombs were hidden in copies of Hafid Keramane's La pacification, livre noir de 6 années de guerre en Algérie, published that month in Lausanne by Nils Andersson's press La Cité. In Le petit soldat we see FLN agents reading from another book published by Andersson, Henri Alleg's La question.

${ }^{14}$ I am still investigating the careers of those députés, but we can already rule out Jean-Marie Le Pen, already an ex-Poujadist but too young to have done much under Vichy. He is, however, involved with Le petit soldat as the député who called for the expulsion of the foreigner Godard for making this film. The name of another 'député poujadiste', Berthommier, is mentioned in one of the several radio broadcasts heard throughout the film, but he was not much older than Le Pen.

${ }^{15}$ Earlier in the film we see a poster for Le petit soldat on the wall of Marianne's apartment.

${ }^{16}$ The voice of the radio announcer appears to be Godard's, as is the case for at least one of the sixteen radio broadcasts heard in Le petit soldat. 